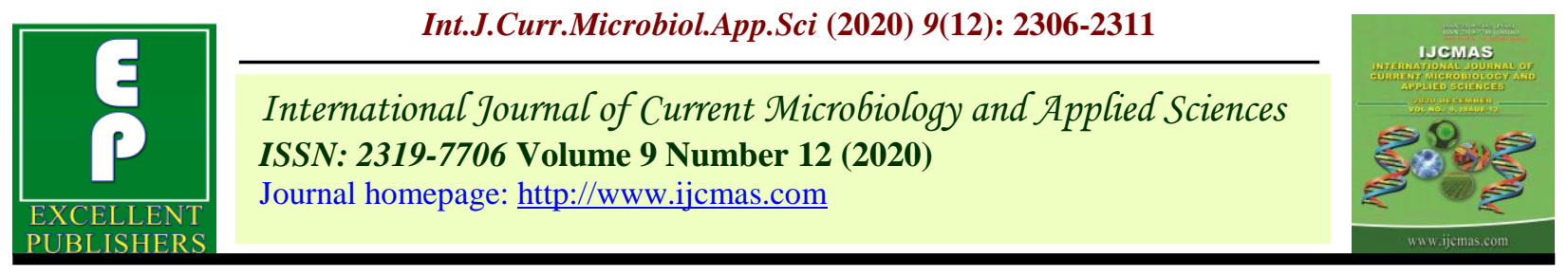

Original Research Article

https://doi.org/10.20546/ijcmas.2020.912.273

\title{
Analysis of Resource Use Efficiency on Beneficiary and Non-Beneficiary Farm Pond Farmers of Major Crops in Akola District, India
}

\author{
K. L. Bachhao*, S. N. Suryawanshi, Sumit B. Wasnik and S. A. Gawande \\ Department of Agriculture Economics and Statistics, PGI, Dr. PDKV Akola, India \\ *Corresponding author
}

\section{A B S T R A C T}

\begin{tabular}{l} 
K e y w o r d s \\
$\begin{array}{l}\text { Beneficiary, Non- } \\
\text { beneficiary, Input } \\
\text { factor, Productivity, } \\
\text { Marginal value } \\
\text { product, Farm pond }\end{array}$ \\
\hline Article Info \\
$\begin{array}{l}\text { Accepted: } \\
\text { 16 November } 2020 \\
\text { Available Online: } \\
\text { 10 December } 2020\end{array}$
\end{tabular}

\section{Keywords}

Beneficiary, Nonbeneficiary, Input Marginal value product, Farm pond

\section{Introduction}

India has been predominantly an agricultural country. Hence, it is true that progress of India is very much dependent on the development of agriculture. The increased agricultural production depends upon the number of factors of which, water play an important role. In an agricultural country like India, the average land holding is very small. The population is steadily increasing without any possibility of increase in land area. The income from cropping for an average farmer is hardly sufficient to sustain his family. The farmer has to be assured of a regular income
The present study entitled, 'Analysis of resource use efficiency of beneficiary and nonbeneficiary farm pond farmers of major crops in Akola district' was undertaken to examine the impact of farm ponds on productivity of various inputs of major crops i.e., Soybean, Tur and Gram. For the present study, 50 beneficiary farmers having farm ponds and 50 non-beneficiary farmers without farm ponds on their field were selected from Telhara tahasil of Akola district. 10 villages from Telhara tahasil were selected purposively and, from each village sufficient samples of beneficiary and non-beneficiary mers were taken randomly for comparison. It is revealed from the study that the

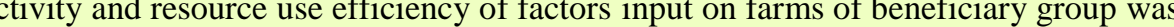
inigher than the non-beneficiary group of farmers, thus farm ponds availability has resulted in increasing factor productivity on beneficiary farms. It also revealed that the MPV of land, human labours, bullock labours, manures \& fertilizers and working capital of eneficiary farms was higher than non-beneficiary farms. It shows higher input factors on beneficiary farms indicate higher input productivity. 
agricultural production in Indian condition particularly lifesaving irrigation. Agriculture is one of the largest and most important sectors in Indian economy. The main occupation of 65 per cent people in India is farming. India has ancient history of tank technology. Runoff collection in irrigation tanks exists in nearly every district in India, but they are more concentrated in coastal districts.

The excess rain water harvested in farm ponds play a vital role in stabilizing crop production through recycling during dry spell in kharif season and for protective irrigation in rabi season. Ponds can be filled by rainfall, as is common with farm and ranch ponds that are sited at a low point and serve to collect runoff from higher reaches in the watershed. Alternatively, farm ponds can be filled with well water from irrigation, which can then be recycled.

The major works of Rain Water Harvesting Structure adopted in the watershed are check dams, farm ponds, nala bunds, contour bunds, vegetative covers etc. which play major role in managing and conserving the soil and water resources. However, farm pond is perceived as best rain water harvesting structure by large majority of farmers.

The empirical investigations are needed to study the resource use efficiency of input factors in inter-size crop models. Hence, the empirical and scientific investigational study of resource use efficiency of input factors in the rural economy of Nellore district is an important phenomenon.

In the present study, an attempt has been made to study the productivity of input factors in beneficiary farmers and non-beneficiary farmers of cultivation of major crops in telhara tahasil of Akola district of Maharashtra state.

\section{Materials and Methods}

This study was based on primary data collected during the year 2017-18 from 50 beneficiary and 50 non beneficiary farmers in Telhara tahsil of Akola district of Maharashtra state in which three major crops were selected i.e., Soybean, Tur and Gram.

The impact of farm ponds activity and resource use efficiency was determined by using the Cobb Douglas production function analysis for beneficiary and non-beneficiary farmers was estimated.

$Y=a x_{1}^{b 1} x_{2}^{b 2} x_{3}^{b 3} x_{4}^{b 4} x_{5}^{b 5} \ldots \ldots \ldots \ldots \ldots x_{n}^{b n}, e^{n}$

Where,

$\mathrm{Y}=$ Gross income in Rs. per farm.

$\mathrm{X}_{1}=$ Land area in hectares per farm.

$\mathrm{X}_{2}=$ Human labour in Rs. per farm.

$\mathrm{X}_{3}=$ Bullock labour in Rs. per farm.

$\mathrm{X}_{4}=$ Expenditure on manure in Rs. per farm

$\mathrm{X}_{5}=$ Expenditure on fertilizers in Rs. per farm.

$\mathrm{X}_{6}=$ Working capital in Rs. per farm.

$\mathrm{a}=$ Intercept.

$b_{1}$ to $b_{n}=$ Regression coefficient of the concerned factors.

The impact of farm pond activities on factor productivity was examined by estimating marginal value products (MVP) of the factor inputs. MVP was calculated using following formula:

$M V P=M P P_{x} P_{y}$

$M V P=\frac{\bar{Y}}{\bar{X}_{n}}$

Where,

MVP = Marginal value of products, $\bar{Y}=$ the estimated output when all the inputs 
(x`s) were held at their geometric mean level, $b_{i}=$ the regression coefficient of the concerned input factor and

$\overline{\mathrm{X}}_{\mathrm{i}}=$ the geometric mean of the $\mathrm{i}^{\text {th }}$ factor.

\section{Results and Discussion}

\section{Per hectare input utilization of soybean, tur and gram}

From table 1 it was found the overall input utilization of soybean for beneficiary and non-beneficiary farmers was found to be 19.37 and 22.67 respectively.

The overall input utilization of tur for beneficiary and non-beneficiary farmers was found to be 25.12 and 25.49 respectively. The overall input utilization of gram for beneficiary and non-beneficiary farmers was found to be 17.18 and 24.92 respectively.

Hence, at overall level use of some input like hired human labour, seeds fertilizers etc. by beneficiary farmers was slightly lower than non-beneficiary farmers. Use of seed and farm yard manures per hectare did not vary much among the beneficiary and nonbeneficiary farmers.

Use of seed and farm yard manure per hectare did not vary much among the beneficiary and non-beneficiary farms. Intergroup comparison of beneficiary and non-beneficiary farmers also revealed the same trend.

The study on inputs use thus revealed that, in general level of input utilization, with few exceptions, did not vary much among beneficiary and non-beneficiary farmers. Whatever variations were there, they could be attributed to the technical guidance received by the beneficiary farmers through their contacts with the extension personnel working in the research area.

\section{Resource use efficiency of inputs}

The regression coefficient of human labour, bullock labour, manure and fertilizers and working capital were positively and significant at 5 to 10 per cent level of significance, which indicate the major contribution of those variables in output. The regression coefficient of bullock labour was found less significant showed less influence of such variable on the output. In this context the study of resource productivity assumes paramour importance. It could be seen from table 2 that the $\mathrm{R}^{2}$ value at overall level for beneficiary and non-beneficiary group was 0.83 and 0.62 , respectively. At overall level regression coefficient of land in beneficiary category was 0.66 against 0.53 for nonbeneficiary category. Regression coefficient of manures and fertilizers for beneficiary and non-beneficiary farm was 0.27 and 0.24 , respectively. For working capital, the regression coefficient for beneficiary group at overall level was 0.62 as against 0.49 for the non-beneficiary group. Thus, the regression coefficients which indicate the productivity of inputs factors were in general, higher for the beneficiary farms than the non-beneficiary category.

Higher regression coefficient and consequently the higher factor productivity for beneficiary farms were obviously due to farm pond availability on these farms. Farm pond availability ultimately made more water available for irrigation on beneficiary farms which resulted in increasing the productivity of land, manures and fertilizers which directly affect the crop yield. Intergroup comparison revealed that the regression coefficients of land, bullock labour, manures and fertilizers and working capital for small category of farm in beneficiary groups were higher than the non-beneficiary groups. Same trend was seen in case of medium group of farmers. 
Table.1 Per hectare input utilization of major selected crops by farmers

\begin{tabular}{|c|c|c|c|c|c|c|c|c|c|c|c|c|c|c|c|c|c|c|c|c|c|c|c|c|c|c|}
\hline \multirow[t]{3}{*}{ Sr. No. } & \multirow[t]{3}{*}{ Particulars } & \multirow[t]{3}{*}{ Unit } & \multicolumn{8}{|c|}{ Soybean } & \multicolumn{8}{|c|}{ Tur } & \multicolumn{8}{|c|}{ Gram } \\
\hline & & & \multicolumn{2}{|c|}{ Small } & \multicolumn{2}{|c|}{ Medium } & \multicolumn{2}{|c|}{ Large } & \multicolumn{2}{|c|}{ Overall } & \multicolumn{2}{|c|}{ Small } & \multicolumn{2}{|c|}{ Medium } & \multicolumn{2}{|c|}{ Large } & \multicolumn{2}{|c|}{ Overall } & \multicolumn{2}{|c|}{ Small } & \multicolumn{2}{|c|}{ Medium } & \multicolumn{2}{|c|}{ Large } & \multicolumn{2}{|c|}{ Overall } \\
\hline & & & B & NB & B & NB & B & NB & B & NB & B & NB & B & NB & B & NB & B & NB & B & NB & B & NB & B & NB & B & NB \\
\hline 1 & Hired human labour & \multirow[t]{5}{*}{ Days } & & & & & & & & & & & & & & & & & & & & & & & & \\
\hline a) & Male & & 27.74 & 25.84 & 12.87 & 16.75 & 9.76 & 11.54 & 15.19 & 20.04 & 21.66 & 20.99 & 21.02 & 22.49 & 20.71 & 19.93 & 21.05 & 21.13 & 17.26 & 13.7 & 11.73 & 13.39 & 7.59 & 13.82 & 12.06 & 13.64 \\
\hline b) & Female & & 42.01 & 38.55 & 22.22 & 24.81 & 19.58 & 24.17 & 25.91 & 31.53 & 29.76 & 24.2 & 25.46 & 25.9 & 24.7 & 25.09 & 26.19 & 24.86 & 12.75 & 12.76 & 15.1 & 11.09 & 9.05 & 10.72 & 12.12 & 11.83 \\
\hline c) & Total & & 69.75 & 64.39 & 35.07 & 41.56 & 29.34 & 37.45 & 41.1 & 51.57 & 51.42 & 45.19 & 46.48 & 48.39 & 45.41 & 45.02 & 47.24 & 45.99 & 30.01 & 26.46 & 26.83 & 24.48 & 16.64 & 24.54 & 24.18 & 25.47 \\
\hline 2 & Bullock labour & & 7.52 & 9.26 & 7.95 & 7.32 & 4.36 & 5.08 & 6.41 & 7.75 & 5.66 & 5.6 & 5.09 & 5.35 & 5.54 & 5.95 & 5.41 & 5.62 & 2.14 & 1.76 & 1.22 & 1.634 & 0.89 & 1.45 & 1.09 & 1.59 \\
\hline 3 & Machinery & Hrs. & 6.16 & 6.68 & 5.36 & 5.27 & 2.29 & 3.8 & 4.33 & 5.63 & 5.17 & 4.22 & 4.87 & 4.98 & 4.24 & 4.76 & 4.69 & 4.55 & 6.57 & 2.44 & 4.6 & 2.623 & 3.29 & 4.09 & 4.55 & 2.88 \\
\hline 4 & Seed & Kg. & 74.87 & 82.19 & 75.127 & 79.39 & 58.38 & 52.41 & 68.36 & 74.32 & 13.81 & 12.33 & 12.7 & 12.81 & 12.56 & 12.21 & 12.91 & 12.43 & 68.02 & 79.85 & 72.62 & 81.9 & 74.93 & 79.95 & 56.84 & 80.4 \\
\hline 5 & Manures & Qtl. & 8.55 & 6.31 & 2.46 & 3.83 & 4.18 & 1.86 & 4.61 & 4.6 & 5.11 & 5.55 & 5.15 & 5.06 & 5.54 & 5.32 & 5.3 & 5.37 & 18.44 & 36.16 & 18.23 & 36.31 & 9.95 & 29.17 & 56.84 & 34.52 \\
\hline 6 & Fertilizers & \multirow[t]{4}{*}{$\mathrm{Kg}$. } & & & & & & & & & & & & & & & & & & & & & & & & \\
\hline a) & $\mathrm{N}$ & & 55.37 & 61.38 & 60.03 & 66.22 & 47.99 & 42.92 & 54.1 & 58.21 & 23.14 & 23.97 & 23.04 & 22.08 & 21.07 & 23.25 & 22.3 & 23.31 & 22.59 & 28.83 & 17.98 & 23.75 & 12.28 & 30.26 & 16.8 & 27.85 \\
\hline b) & $\mathrm{P}$ & & 84.14 & 114.541 & 119.331 & 130.96 & 96.73 & 77.99 & 101.84 & 110.04 & 41.38 & 46.64 & 45.88 & 44.78 & 42.79 & 47.14 & 43.56 & 46.27 & 55.55 & 39.12 & 35.5 & 45.51 & 27.09 & 53.36 & 36.95 & 44.2 \\
\hline c) & Total & & 139.51 & 175.921 & 179.361 & 197.18 & 144.72 & 120.91 & 155.94 & 168.25 & 64.52 & 70.61 & 68.92 & 66.86 & 63.86 & 70.39 & 65.86 & 69.58 & 78.14 & 67.95 & 53.48 & 69.26 & 39.37 & 83.62 & 53.75 & 72.05 \\
\hline 7 & Family labour & \multirow[t]{4}{*}{ Days } & & & & & & & & & & & & & & & & & & & & & & & & \\
\hline a) & Male & & 11.39 & 11.72 & 9.38 & 8.56 & 7.12 & 9.23 & 8.96 & 10.3 & 12.07 & 10.59 & 11.16 & 11.16 & 11.37 & 11.22 & 11.46 & 10.89 & 19.05 & 17.33 & 13.19 & 19.01 & 7.28 & 13.16 & 12.23 & 16.77 \\
\hline b) & Female & & 11.26 & 11.07 & 9.53 & 15.18 & 10.7 & 12.04 & 10.41 & 12.37 & 14.11 & 14.52 & 13.11 & 15.16 & 13.88 & 14.15 & 13.66 & 14.6 & 9.05 & 9.63 & 5.11 & 7.11 & 2.34 & 6.2 & 4.95 & 8.15 \\
\hline c) & Total & & 22.65 & 22.79 & 18.91 & 23.74 & 17.82 & 21.27 & 19.37 & 22.67 & 26.18 & 25.11 & 24.27 & 26.32 & 25.25 & 25.37 & 25.12 & 25.49 & 28.1 & 26.96 & 18.3 & 26.12 & 9.72 & 19.36 & 17.18 & 24.92 \\
\hline
\end{tabular}

(B - Beneficiary and NB - Non-Beneficiary) 
Table.2 Production function estimates for beneficiary and non-beneficiary farms

\begin{tabular}{|c|c|c|c|c|c|c|c|c|c|}
\hline \multirow{3}{*}{$\begin{array}{l}\text { Sr. } \\
\text { No. }\end{array}$} & \multirow{3}{*}{ Input } & \multicolumn{8}{|c|}{ Regression coefficient } \\
\hline & & \multicolumn{2}{|c|}{ Small } & \multicolumn{2}{|c|}{ Medium } & \multicolumn{2}{|c|}{ Large } & \multicolumn{2}{|c|}{ Overall } \\
\hline & & B & NB & B & NB & B & NB & B & NB \\
\hline 1 & Intercept & $\begin{array}{c}3.19 \\
(0.48)\end{array}$ & $\begin{array}{c}2.66 \\
(0.43)\end{array}$ & $\begin{array}{c}0.97 \\
-(0.03)\end{array}$ & $\begin{array}{c}2.56 \\
(0.42)\end{array}$ & $\begin{array}{c}2.90 \\
(0.33)\end{array}$ & $\begin{array}{c}4.46 \\
(0.65)\end{array}$ & $\begin{array}{c}2.53 \\
(0.34)\end{array}$ & $\begin{array}{c}3.22 \\
(0.50)\end{array}$ \\
\hline 2 & Land $\left(\mathrm{X}_{1}\right)$ & $\begin{array}{c}0.80 * * \\
(0.23)\end{array}$ & $\begin{array}{c}0.53 * * \\
(0.24)\end{array}$ & $\begin{array}{c}0.73 \\
(0.41)\end{array}$ & $\begin{array}{l}0.66^{* * *} \\
(0.41)\end{array}$ & $\begin{array}{c}0.47 * * \\
(0.09)\end{array}$ & $\begin{array}{c}0.41 \\
(0.56)\end{array}$ & $\begin{array}{c}0.66 * * \\
(0.24)\end{array}$ & $\begin{array}{c}0.53^{* *} \\
(0.40)\end{array}$ \\
\hline 3 & $\begin{array}{l}\text { Human labour } \\
\left(\mathrm{X}_{2}\right)\end{array}$ & $\begin{array}{c}0.30 \\
(0.27)\end{array}$ & $\begin{array}{c}0.39 * * \\
(0.23)\end{array}$ & $\begin{array}{c}0.48 \\
(0.55)\end{array}$ & $\begin{array}{c}0.24 \\
(0.29)\end{array}$ & $\begin{array}{c}0.15 \\
(0.71)\end{array}$ & $\begin{array}{c}0.11 \\
(0.61)\end{array}$ & $\begin{array}{c}0.30 \\
(0.51)\end{array}$ & $\begin{array}{c}0.24 \\
(0.37)\end{array}$ \\
\hline 4 & $\begin{array}{l}\text { Bullock } \\
\text { labour }\left(X_{3}\right)\end{array}$ & $\begin{array}{c}0.15 \\
(0.22)\end{array}$ & $\begin{array}{c}0.11 \\
(0.24)\end{array}$ & $\begin{array}{c}0.13^{* * * *} \\
(0.37)\end{array}$ & $\begin{array}{l}-0.05 \\
(0.25)\end{array}$ & $\begin{array}{c}0.065 * * * \\
(0.36)\end{array}$ & $\begin{array}{c}0.04 \\
(0.93)\end{array}$ & $\begin{array}{c}0.062^{* *} \\
(0.31)\end{array}$ & $\begin{array}{l}0.04^{* * *} \\
(0.47)\end{array}$ \\
\hline 5 & $\begin{array}{l}\text { Manures and } \\
\text { fertilizers } \\
\left(\mathrm{X}_{4}\right)\end{array}$ & $\begin{array}{c}0.23 * * \\
(0.06)\end{array}$ & $\begin{array}{c}0.23 \\
(0.12)\end{array}$ & $\begin{array}{c}0.31 \\
(0.34)\end{array}$ & $\begin{array}{c}0.29 \\
(0.63)\end{array}$ & $\begin{array}{c}0.27 * * \\
(1.09)\end{array}$ & $\begin{array}{c}0.20 \\
(0.10)\end{array}$ & $\begin{array}{l}0.27 * * \\
(0.49)\end{array}$ & $\begin{array}{c}0.24 \\
(0.28)\end{array}$ \\
\hline 6 & $\begin{array}{l}\text { Working } \\
\text { capital }\left(\mathrm{X}_{5}\right)\end{array}$ & $\begin{array}{c}0.13^{* *} \\
(0.13)\end{array}$ & $\begin{array}{c}0.45^{* *} \\
(0.08)\end{array}$ & $\begin{array}{c}0.64^{* *} \\
(0.17)\end{array}$ & $\begin{array}{c}0.53 \\
(0.12)\end{array}$ & $\begin{array}{l}0.63^{*} \\
(0.17)\end{array}$ & $\begin{array}{c}0.49 \\
(0.12)\end{array}$ & $\begin{array}{l}0.62^{*} \\
(0.15)\end{array}$ & $\begin{array}{l}0.49^{*} \\
(0.10)\end{array}$ \\
\hline & $\mathrm{R}^{2}$ & 0.86 & 0.60 & 0.86 & 0.64 & 0.82 & 0.62 & 0.83 & 0.62 \\
\hline
\end{tabular}

(Figure in parentheses are standard error of respective variable. $*, * *$ and $* * *$ indicated the level of significance at 10,5 and 1 per cent, respectively)

Table.3 Marginal value products of input

\begin{tabular}{|c|l|c|c|}
\hline Sr. No. & Particulars & \multicolumn{2}{|c|}{ Marginal value of product } \\
\cline { 3 - 4 } & & Beneficiary & Non-beneficiary \\
\hline $\mathbf{1}$ & Land & 10835.90 & 6772.72 \\
\hline $\mathbf{2}$ & Human labour & 0.67 & 0.42 \\
\hline $\mathbf{3}$ & Bullock labour & 0.81 & 0.32 \\
\hline $\mathbf{4}$ & Fertilizers and manures & 4.17 & 3.52 \\
\hline $\mathbf{5}$ & Working capital & 1.09 & 0.29 \\
\hline
\end{tabular}

For large group of beneficiary's categories, the regression coefficient of land, manures and fertilizers and working capital were higher than the large farms of non-beneficiary category.

The study thus reveals that the productivity of the input factors on farms of the beneficiary group was higher than the non-beneficiary group. Thus, farm pond availability has resulted in increasing factor productivity on beneficiary farms.

\section{Marginal value products of input}

It could be seen from table 3 that the marginal value product (MVP) of land, human labour, bullock labours, manures and fertilizers and working capital at overall level of beneficiary farms was higher than non-beneficiary farms. This higher (MVP) of input factors on beneficiary farms indicate higher input productivity on these farms. Deokate et al., (2016) in their study reported that for soybean crop, the MVP values of all the crucial inputs excepts machine labour, phosphorus and 
potassium fertilizers are greater than marginal cost, indicating that these inputs are used optimally and there is a scope to increase these inputs for obtaining better yield.

Lokanadha Reddy and Radhakrishna Reddy (2013) observed that the MVPs of some input variables are substantially higher than unity, implying sub-optimal levels of use of these inputs by the cultivators.

In conclusion the level of input utilization, with few exceptions, did not vary much among beneficiary and non-beneficiary farmers. The productivity of the input and resource use efficiency of factors on farms of the beneficiary group was higher than the non-beneficiary group. Thus, farm pond availability has resulted in increasing factor productivity on beneficiary farms.

\section{References}

Anonymous 2013. Impact of farm ponds on beneficiary farmers of western Viderbha. Research review committee project submitted, on $2^{\text {nd }}$ April 2013 at RRC meeting Dr. PDKV, Akola.

Chavai, A. M., U. V. Rakshe and S. B Shinde. 2015. Impact of farm ponds on beneficiary farmers of Maharashtra. International J. of tropical Agril., 33(4): 3525-3528.

Desai, R., B. L. Patil., L.B. Kunnal., H. Jayshree and H. Basvaraj., 2006. Impact assessment of farm-ponds in Dharwad district of Karnataka. Karnataka J. of Agril. sciences. 20 (2) 426- 427.

Deokate, T. B., Gavali A.V. and Yadav D.B., 2016. Resourse use efficiency of soybean production in Maharashtra. J. of Agril. Res. Technology. 41(2): 282285.

Lokanadha Reddy, E. and Reddy D. Radhakrishna, 2013. A Study on Resource Use Efficiency of Input Factors with Reference to Farm Size in Paddy Cultivation in Nellore District. IOSR Journal of Humanities and Social Science (IOSR-JHSS) 17(1): 48-55.

Mondala, B., Singh A. and Jahb. Girish, 2012. Impact watershed development programmes on farm specific technical efficiency study in Bundelkhand region in Madhya Pradesh. Agril. Econ. Res. Review: 25 (2) 299-308.

Mishra, P. K. and Shau R.M., 1994. Resource productivity and need resource adjustment in gram cultivation in MP. Agricultural situation in India 49(07): 524-532.

Pagire, B.V. 1989. Impact watershed development programmes on crop productivity and agriculture income. Indian J. of Agril. econ., 44(1) 270-271.

Sindhu, R. S., Poonia G. S. and Singh S.., 1991. Determining the economic viability of watershed project and their impact on productivity and in course in Kandi area of Punjab. Agril. Situation in India. 45 (11): 735-742.

\section{How to cite this article:}

Bachhao, K. L., S. N. Suryawanshi, Sumit B. Wasnik and Gawande, S. A. 2020. Analysis of Resource Use Efficiency on Beneficiary and Non-Beneficiary Farm Pond Farmers of Major Crops in Akola District, India. Int.J.Curr.Microbiol.App.Sci. 9(12): 2306-2311. doi: https://doi.org/10.20546/ijcmas.2020.912.273 